\title{
Research on the Development of Management Accounting in Small and Medium-Sized Enterprises in China
}

\author{
Bingxin Du' ${ }^{1}$, Jiaxu Jiang ${ }^{1}$ Xiuzhi Ji ${ }^{2}$ \\ ${ }^{1}$ Business School, Beijing Normal University, Beijing, China \\ ${ }^{2}$ Library of Renmin University of China, Beijing, China \\ Email: mlbsabc@sina.com
}

How to cite this paper: Du, B.X., Jiang, J.X. and Ji, X.Z. (2018) Research on the Development of Management Accounting in Small and Medium-Sized Enterprises in China. Open Journal of Accounting, 7, 19-24.

https://doi.org/10.4236/ojacct.2018.71002

Received: October 16, 2017

Accepted: November 19, 2017

Published: November 22, 2017

Copyright $\odot 2018$ by authors and Scientific Research Publishing Inc. This work is licensed under the Creative Commons Attribution International License (CC BY 4.0).

http://creativecommons.org/licenses/by/4.0/

\begin{abstract}
In the early $20^{\text {th }}$ century, management accounting was created with Taylor's theory of scientific management. Management accounting is a continuous improvement process that provides value added value, design, measure and manage financial and non-financial information systems for enterprises. This process directs the management actions, motivates behaviour, supports and creates cultural values, which are needed to achieve organizational strategy, tactics and business objectives. The research and application of management accounting in China started late. It started in the late 1970s and early 1980s. During the period of about 30 years, management accounting has made great progress in both theory and practice. Many facts have proved that China's management accounting has gradually shifted from quantity and quota management to management of cost and value, and from project and department management to comprehensive and strategic management. In recent years, with the implementation of fiscal policies such as department budget, investment review and performance appraisal, "comprehensive budget", "zero-base budget", "budget control", "responsibility assessment" and other modern management accounting theories and methods have been applied in various enterprises in China. But the time that management accounting is formed and developed in China is not long after all. There are many defects and deficiencies in China's management accounting. The theoretical structure, scope of research and practical application of management accounting are to be improved and enriched, and there is still considerable space for development. The problem is more serious in small and medium-sized enterprises [1]. This paper studies the current development status of management accounting in small and medium-sized enterprises and factors that affect the management accounting in the small and medium-sized enterprises, then proposes solu-
\end{abstract}


tions to meet the development needs of management accounting in small and medium-sized enterprises.

\section{Keywords}

Management Accounting, Small and Medium-Sized Enterprises

\section{Introduction}

Management accounting is also called analysis report accounting, and it's a management term. It is a branch of accounting and it refers that accounting personnel use the information provided by financial accounting and by processing, collating and reporting other information to plan and control the daily economic activities of the enterprise's management personnel at all levels and help policymakers make specific decisions through a series of specialized methods in the aim of improving economic benefits of the enterprise.

The small and medium-sized enterprises in China have been developing slowly, which has become an important part of the national economy. The complex and changeable market environment makes the development of small and medium-sized enterprises face more opportunities, together with more competition and challenges long-term development in order to achieve long-term developments. Traditional accounting has not been able to better adapt to the needs of the strategic management of small and medium-sized enterprises in China, and the new situation shows more limitations [2]. In order to meet the competitive demand of small and medium-sized enterprises, promote the longterm development of enterprises and create more economic value, management accounting will receive more and more attention from small and medium-sized enterprises, and become a new means for the healthy development of small and medium-sized enterprises.

At present, there are still many problems in the development of small and medium-sized enterprises. China's current large number of small and medium enterprises management level is very low, for example, some employees have low quality and the leadership has a superficial understanding of management accounting. Moreover, the weak foundation of management has resulted in low efficiency, low management level, poor economic performance and poor income and other bad situations. Overall, management accounting is not widely used in Chinese enterprises at present. But with the rising production costs, increasing wages, and fierce market competitions, management accounting will become the fundamental force for efficient management of modern enterprises.

Management accounting itself is to provide information and solutions for business operations and decisions. Its failure to be carried out reasonably and comprehensively in application has hindered the developments of the small and medium-sized enterprises [3]. 


\section{The Elements Which Influence the Application of Management Accounting in Small and Medium-Sized Enterprises in China}

\subsection{The Particularity of Chinese Social System and Management System}

China is still in the transit from planned economy to market economy, so the socialist market system is still not perfect. Market economy is often affected by planned economy, because the government usually overdoes business operation during the course of the transition economy. Government intervention is usually politically motivated. It is this particularity that causes the difference between the application environment of China's management accounting and the western developed countries' application environment of management accounting [4].

\subsection{The Management Consciousness of Management and Accounting Management Staff Are Generally Not High}

There are a lot of managers who have the shackles of traditional thoughts in modern Chinese small and medium-sized enterprises nowadays. Some innate ideas or habits usually have an impact on them. The human factor is crucial to promote management accounting in small and medium-sized enterprises in China. Whether the leaders at all levels can recognize the situation, change the concept, actively advocate and push forward vigorously the management accounting or not is the key that management accounting can successfully be applied in small and medium-sized enterprises in China. At present, the management consciousness is weak [5]. Entrepreneurs not only need to know how to operate, but also are necessary to know how to manage it. But in the present situation, some enterprises have not met such requirements. Under the influence of traditional concepts and the constraints of social or traditional hierarchy, the information and scheme provided by the management accounting system cannot be properly used.

These days, businesses are not always planning for the long term, but focusing on their immediate short-term interests. The reason is that companies can't use long-term benefits correctly. The use of management accounting should be complementary to the enterprise's own operating mechanism. And the management level of the enterprise is closely related to the management accounting.

\subsection{There is no Normative and Sound Management Accounting Basic Theory System}

The internal management system of small and medium-sized enterprises is not perfect, and the strategic management accounting is not well understood by the small and medium-sized enterprises. For the study of management accounting, both China and the western countries have been focusing on the method and ignore the theoretical structures, focusing on the analysis of specific problems 
and ignores the integrity. But the theoretical system is the basis of any discipline. Its comprehensiveness and system are the key to its existence and promotion of its application. For a long time, the western countries do not pay attention to the research of the systematic theory of management accounting, and China's management accounting is still in the translation and introduction stage of western theories. Besides, it is divorced from enterprises' management practices. So, we repeat other countries' way of development, but we create little, and we make many special studies but few systematic theory studies, which make it difficult for us to make greater use of management accounting research [6].

\section{Suggestions on Improving the Financial Management of Small and Medium-Sized Enterprises}

\subsection{Small and Medium-Sized Enterprises Should Establish Sophisticated Management System to Achieve a Better Strategic Management Accounting Development Environment}

Enterprises need to fully and reasonably tap existing resource potential in order to make business decisions more scientific and make the market behavior of enterprises more accord with objective requirements. The establishment of a budget system suitable for enterprises can further improve the comprehensive profitability of enterprises. Small and medium-sized enterprises operate in a smaller scale, but they should also have the internal management system and the clear division of responsibilities in order that the personnel of all departments can handle the problems encountered by the department and to enhance the operation efficiency of small and medium-sized enterprises to get better development for enterprises. To establish the necessary management system, the small and medium-sized enterprises should refer to the successful experience and theoretical knowledge of some enterprises. The efficient management system can guide the behavior of enterprises' personnel in the work and promote more effective operation of enterprises.

\subsection{Strengthen Training for Managers and Accountants and Improve the Quality of Accountants}

The managers of the enterprise usually work in various departments of the enterprise for many years and they have rich management experience. But there is still some deficiency in management accounting theoretical knowledge reserve for them. For an enterprise, the strategic management concept of business leaders is more important. The accounting staff can give full play to the effectiveness of accounting staff in forecasting, planning and other aspects only when they have sufficient and solid management accounting knowledge. Leaders of enterprises should change their minds, discard the erroneous concepts of strategic management accounting, and improve their learning abilities. This also requires government departments and industry associations to strengthen the training on strategic management accounting content for small and medium-sized enterprises. Emphasis should be put on educating managers and accountants to improve 
their professional skills. This can help to manage the business better and more smoothly and play the role of corporate financial management more effectively.

\subsection{Strengthening the Information Construction for Management Accounting}

Informationization is an important means of management accounting. With the development of management accounting informatization, the integration of business information and accounting information is accelerated. Informatization has put forward a new demand for management accounting construction. The level of application of modern information technology directly influences the development process of management accounting.

At present, the informatization of management accounting develops slowly. The main reason is that not enough attention was paid to it and there are underlying errors in the managers' and accountants' understanding of it. Some people think that accountant who have the ability to prepare statements, do a good job in the budget, strengthen analysis can be called the management accounting. So first, accounting personnel should realize the importance and urgency of realizing accounting informatization from the perspective of society. Secondly, the overall planning of informationization of enterprises management and the development planning of accounting informationization should combine with the actual needs of the enterprises and should integrate the management philosophy of the enterprises into the systematic managements [7].

To strengthen the construction of modern enterprise system and create a good environment for management accounting, the task and function of management accounting provides a new way of thinking. Only by establishing a good environment can management accounting be promoted and applied. Only in this way, the technology, system and method of management accounting can be more adapted to the requirements of the enterprise environment and get better development.

\section{Conclusion}

With the development of management especially in its application in practice, management accounting will have a far-reaching impact on cost accounting, prediction and decisions' making, analysis and control, integrity and practicability of performance evaluation system, and promote the integration and development of enterprise management, financial accounting theory and other disciplines. With the development of economy, the development of management accounting in China will be more rapid and extensive in the future. Management accounting theory will be adopted by more small and medium-sized enterprises, but the application of management accounting in small and medium-sized enterprises in China has yet to be improved. This will be a process of long-term development and continuous improvement. The development of management accounting can help to realize the competitive advantage of the whole enterprise, 
which is beneficial to the acquisition of corporate strategic goal [8]. To play the role of management accounting in small and medium-sized enterprises in China, we need to cultivate the strategic management consciousness of small and medium-sized enterprises, actively explore and innovate in the process of practice, combine management accounting with financial accounting.

\section{References}

[1] Zhao, H. (2006) The Current Situation of Management Accounting and Its Innovative Development in China. Friends of Accounting, 5, 2-9.

[2] Guo, Y.Q. (2006) The Thinking about the Application of Management Accounting in Enterprises. Northern Economy and Trade, 2, 14-18.

[3] Wu, Y.J. (2012) To Strengthen the Application of Strategic Management Accounting in Small and Medium-Sized Enterprises in China. Entrepreneurial Studies, 10, 25-29.

[4] Roland, G. (2000) Transition and Economics Massachusetts Institute of Technology. 12, 16-19.

[5] Carpenter, C.G. and Strawser, R.H. (1970) Job Selection Preferences of Accounting Students. The Journal of Accountancy, 12, 21-28.

[6] Beyk, B.S.L. (2011) Cultural Analyzing of Management Accounting Application. Ninth Congress Accounting in Iran, 9, 14-18.

[7] Joshi, P.L., Bremser, W.G. and Al-Ajmi, J. (2008) Perceptions of Accounting Professionals in the Adoption and Imple mentation of a Single Set of Global Accounting Standards: Evidence from Bahrain. Advances in Accounting, Incorporating Advances in International Accounting, 24, 41-48.

[8] Etemadi, H., Dianati, D.Z., Bazaz, S.B. and Parameswaran, R. (2009) Culture, Management Accounting and Managerial Performance: Focus Iran. Advances in Accounting, Incorporating Advances in International Accounting, 25, 216-225. 